\title{
Pengembangan Model Permainan Olahraga Freeball pada Pembelajaran Penjas Adaptif Anak Tunagrahita di SLB Se-Kabupaten Kendal
}

\author{
Yoga Lilo Anung Anindhito ${ }^{1 凶}$
}

Jurusan Pendidikan Jasmani Kesehatan dan Rekreasi, Fakultas Pendidikan IImu Pengetahuan Sosial dan Keolahragaan, Universitas PGRI Semarang, yogaliloo@gmail.com

\section{Article Info}

History Articles

Submitted : 20 Januari 2020

Reviewed: 12 April 2020

Accepted: 18 Juli 2020

\section{Keywords}

Anak Tunagrahita;

Penjas Adaptif;

Permainan Olahraga

Freeball.

\section{Abstrak}

Penelitian ini bertujuan untuk mengembangkan Model Permainan Olahraga Freeball pada Pembelajaran Penjas Adaptif di SLB Se Kabupaten Kendal dan mengetahui kelayakan produk permainan olahraga Freeball berdasarkan penilaian ahli penjas adaptif, ahli permainan modifikasi, dan siswa tunagrahita di SLB. Validasi dilakukan oleh ahli materi penjas adaptif, ahli materi permainan modifikasi. Produk yang dikembangkan diuji kelayakan kepada siswa tunagrahita di SLB se Kabupaten Kendal.Hasil penelitian menunjukkan bahwa tingkat kelayakan model permainan olahraga Freeball pada pembelajaran penjas adaptif anak tunagrahita memperoleh penilaian: 1) Ahli materi I pada tahap akhir diperoleh nilai $87,7 \%$ yang termasuk dalam kategori "Layak", 2) Ahli materi II tahap akhir diperoleh nilai 84,6\% yang termasuk dalam kategori "Layak", 3) Responden dalam skala besar dari 20 siswa, 18 menyatakan layak dengan persentase $80 \%$ sedangkan 2 siswa menyatakan cukup layak dengan persentase $20 \%$ yang termasuk dalam kategori "Layak" Respon siswa terhadap model permainan Freeball ini pada saat dilakukan uji coba rata-rata menunjukkan respon positif dengan mendapatkan persentase $\geq 70 \%$ setiap indikatornya. Dengan demikian Model permainan olahraga Freeball pada pembelajaran penjas adaptif anak tunagrahita di SLB se Kabupaten Kendal ini layak digunakan sebagai alat pembelajaran penjas adaptif di sekolah SLB.

\begin{abstract}
This study aims to develop the Model of Freeball Sports Games in Adaptive Physical Education in SLB in Kendal Regency and to determine the feasibility of Freeball sports game products based on the assessment of adaptive physical experts, modification game experts, and retarded students in SLB. Validation was carried out by adaptive physical material experts, modification game material experts. The developed product was tested for eligibility for mentally retarded students in SLB in Kendal Regency. The results of the study showed that the feasibility level of the Freeball sports game model on adaptive learning for mentally retarded children was assessed: 1) Expert material I at the final stage obtained a value of $87.7 \%$ which was included in the "Eligible" category, 2) The final stage II expert material obtained a value of $84.6 \%$ which is included in the "Eligible" category, 3) Respondents on a large scale of 20 students, 18 declared worthy of a percentage of $80 \%$ while 2 students declared quite decent with the percentage of $20 \%$ included in the "Eligible" category of students' responses to this Freeball game model when tested on average showed a positive response by getting a percentage of $\geq 70 \%$ for each indicator. Thus the Freeball sports game model in adaptive physical education learning for mentally retarded children in SLB in Kendal Regency is feasible to be used as an adaptive education learning tool in SLB school.
\end{abstract}




\section{PENDAHULUAN}

Pendidikan adalah proses dimana
masyarakat, melalui lembaga-lembaga
pendidikan (sekolah, perguruan tinggi atau lembaga-lembaga lain), dengan sengaja mentransformasikan warisan budayanya, yaitu pengetahuan, nilai-nilai dan ketrampilanketrampilan, dari generasi ke generasi. Sedangkan pendidikan jasmani adalah bagian dari proses pendidikan secara keseluruhan. Tujuan umum pendidikan jasmani juga selaras dengan tujuan umum pendidikan. Tujuan belajar adalah menghasilkan perubahan perilaku yang pekat. Proses belajar dalam pendidikan jasmani juga bertujuan untuk menimbulkan perubahan perilaku. Guru mengajar dengan maksud agar terjadi proses belajar secara sederhana, pendidikan jasmani tak lain adalah proses belajar untuk bergerak, dan belajar gerak. Selain belajar dan dididik melalui gerak untuk mecapai tujuan pembelajaran, dalam pendidikan jasmani anak diajarkan untuk bergerak melalui pengalaman itu anak akan terbentuk perubahan dalam aspek jasmani dan rohaninya (Dwi Siswoyo, $2007: 1$ 8). Menurut subagyo (2008: 1-4) dalam skripsi Retno Wahyu Ningsih (2017) Mengungkapkan bahwa pendidikan jasmani dan kesehatan adalah suatu proses pendidikan yang diarahkan untuk mendorong, mebimbing, mengembangkan dan membina kemampuan jasmani dan rohani serta kesehatan siswa dan lingkungan hidupnya, agar tumbuh dan berkembang jasmani dan rohani serta kesehatan siswa lingkungan hidupnya agar tumbuh dan berkembang secara harmonis dan optimal sehingga mampu melaksanakan tugas bagi dirinya dan pengembangan bangsa.

Adapun pendidikan bagi anak tunagrahita dapat dilakukan dengan berbagai cara, antara lain melalui pembelajaran pendidikan jasmani olahraga dan kesehatan. Manfaat pendidikan jasmani olahraga dan kesehatan telah teruji dalam upaya memberdayakan manusia. Diperlukan adanya model pembelajaran dalam pendidikan jasmani sebgai upaya pengembangan pemberdayaan anak tunagrahita. Salah satu bentuk program yang sesuai dengan anak tunagrahita adalah program pendidikan jasmani adaptif. Di Indonesia ini banyak terjadi kesenjangan antara anak berkubutuhan khusus dengan anak normal. Anak berkebutuhan khusus adalah anak dengan karakteristik khusus yang berbeda dengan anak pada umumnya tanpa selalu menunjukan pada ketidakmampuan mental, emosi atau fisik. Anak berkebutuhan khusus memiliki keunikan tersendiri dalam jenis dan karakteristiknya, yang membedakan dari anak-anak normal pada umumnya. Salah satunya yaitu anak yang tidak mampu beradaptasi dengan lingkungan normal dan membutuhkan layanan, perawatan, supervisi, kontrol dan dukungan dari pihak luar, salah satunya keluarga, lingkungan dan pendidikan. Anak berkebutuhan khusus adalah anak yang dalam proses pertumbuhan atau perkembangan mengalami kelainan atau penyimpangan fisik mental-intelektual sosial atau emosional dibanding dengan anak-anak lain seusianya, sehingga mereka memerlukan pelayanan khusus (Darmawanti dan jannah, 2004: 15).

Terdapat banyak kriteria yang dialami anak berkebutuhan khusus, salah satunya yaitu anak berkebutuhan tunagrahita yang mana dalam penelitian ini akan sering disebutkan di dalam penelitian ini. "Anak tunagrahita adalah anak dengan keterbelakangan mental yang mempunyai kemampuan intelektual dibawah rata - rata. Yang mana memiliki arti sama yang menjelaskan kondisi anak yang kecerdasannya dibawah rata-rata dan ditandai dengan keterbatasan intelegensi dan ketidakcakapan dalam interaksi sosial" (Somantri, 2007 :103). 
Penyandang tunagrahita juga mengalami masalah dalam penyesuaian diri yaitu kesulitan dalam berhubungan dengan kelompok maupun individu di sekitarnya dan hal ini di pengaruhi akibat kecerdasan yang dibawah rata - rata (amin 1997). Meskipun anak termasuk kedalam kategori anak tunagrahita, tetapi mereka juga memiliki hak yang sama seperti anak normal pada umumnya. Anak tunagrahita berhak mendapat kasih sayang yang sama dari kedua orangtuanya, keluarga, lingkungan dan pendidikan yang layak yang memenuhi setiap kebutuhannya. Sebagaimana diketahui bahwa anak dengan berkebutuhan khusus memiliki kebutuhan khusus sesuai dengan kategorinya yang harus dipenuhi, baik di rumah, lingkungan atau sekolah terlebih bagi anak tunagrahita. Anak tunagrahita memiliki keunikan tersendiri dalam jenis dan karakteristiknya, yang membedakan dari anak-anak normal pada umumnya. Salah satunya yaitu anak yang tidak mampu beradaptasi dengan lingkungan normal dan membutuhkan layanan, perawatan, supervisi, kontrol dan dukungan dari pihak luar, salah satunya keluarga, lingkungan dan pendidikan. Anak tunagrahita juga membutuhkan aktivitas fisik olahraga seperti anak normal pada umumnya, namun di sekolah-sekolah luar biasa di Semarang kurangnya aktivitas olahraga pada siswa, sehingga anak tunagrahita kurang melakukan aktivitas fisik yang menghambat pertumbuhan dan perkembangan organ yang ada dalam tubuhnya. Padahal di usia remaja mereka sedang dalam masa pertumbuhan dan perkembangan yang mana harus banyak melakukan aktivitas fisik seperti anak normal pada umumnya.

Berdasarkan hasil observasi disekolah, ditemukan permasalahan kurangnya aktivitas olahraga dan kesulitan anak tunagrahita dalam melakukan aktivitas permainan bola besar dikarenakan dalam permainan bola besar membutuhkan kemampuan motorik yang komplek serta anak tunagrahita sulit memahami berbagai macam teknik dasar yang meliputi passing, dribbling maupun pemahaman peraturan permainan bola besar. Kebanyakan mereka hanya melakukan aktivitas olahraga bola besar dengan melempar bola tanpa adanya permainan kompetisi atau kerjasama tim. Padahal olahraga yang membutuhkan kerjasama antar tim akan membentuk suatu karakter yang baik pada anak. seperti, saling menghargai satu sama lain, kerjasama, kepercayaan diri, kedisiplinan, serta aktivitas gerak aktif dalam permainan yang akan melatih kemampuan motorik pada anak tersebut. Bahkan, dalam kurun waktu satu minggu pernah tidak melakukan aktivitas olahraga sama sekali dikarenakan tidak adanya guru penjas yang khusus mengajar pendidikan jasmani adaptif.

Maka dari itu penulis membuat suatu permainan olahraga bola besar yang sudah dimodifikasi peraturan dan permainannya dengan nama freeball, yang mana penulis memodifikasi permainan olahraga tersebut agar anak berkebutuhan khusus (tunagrahita) dapat melakukan aktivitas olahraga bola besar serta menunjukkan kepercayaan dalam dirinya dan melatih kemampuan motorik pada anak tunagrahita. Disini penulis ingin memadukan dan membuktikan bahwa anak berkebutuhan khusus itu juga sama seperti anak normal pada umumnya, mereka juga dapat menunjukkan kemampuan nya dalam olahraga yang sudah dimodifikasi ini. Permainan olahraga freeball adalah perpaduan antara olahraga handball dan futsal yang dirubah peraturan dan cara bermainnya. Yang bertujuan agar memudahkan anak berkebutuhan khusus memahami bagaimana peraturan permainan dan melakukan jalannya permainan tersebut. Permainan 
olahraga freeball dibuat untuk melatih kepercayaan diri serta kemampuan motorik pada anak berkebutuhan khusus dan membantu anak tunagrahita dalam melakukan aktivitas dalam olahrga bola besar. Selain itu olahraga ini juga mudah dilakukan mulai dari teknik dasar dalam permainan serta peraturan yang disederhanakan dalam jalannya permainan. Permainan olahraga freeball juga dapat membentuk suatu karakter yang baik pada anak. Dalam permainan ini dibutuhkan kerjasama antar tim untuk memenangkan pertandingan atau permainannya, hal ini akan memunculkan tindakan saling menghargai satu sama lain, kerjasama, motivasi, kedisiplinan dan kepercayaan diri pada anak tunagrahita yang akan berdampak positif terhadap karakter anak tunagrahita tersebut.

\section{METODE}

Penelitian dan pengembangan yang menghasilkan produk tertentu untuk bidang administrasi, pendidikan, dan sosial lainnya yang masih rendah. Agar dapat menghasilkan produk tertentu peneliti membuat suatu produk model permainan olahraga freeball untuk meningkatkan motorik pada anak tunagrahita dalam pembelajaran penjas di SLB. Prosedur pengembangan sangat penting dalam pelaksanaan penelitian yang digunakan untuk rancangan sesuai dengan rencana yang telah dibuat dan prosedur ilmiah yang ada. Adapun tahapan-tahapan dalam melakukan penelitian pengembangan yang akan dilakukan antara lain:

1. Potensi dan masalah, melakukan observasi disekolah mencari permasalahan yang ada di sekolah SLB yang dialami anak tunagrahita

2. Melakukan pengumpulan data informasi dan observasi lapangan. Langkah ini ditujukan untuk analisis kebutuhan dengan tujuan menentukan apakah model permainan atau produk yang dibuat memang dibutuhkan atau tidak dan menentukan kajian pustaka

3. Mengembangkan atau merancang produk awal, yaitu membuat peraturan permainan Olahraga Freeball

4. Validasi produk, uji kelayakan dengan ahli materi apakah produk yang dirancang layak atau tidak untuk di uji coba kan dengan menggunakan ahli dibidang pendidikan jasmani adaptif dan ahli dibidang pembelajaran permainan modifikasi. Setelah dilakukan evaluasi oleh para ahli, langkah selanjutnya yaitu dilakukan uji coba satu dengan skala kecil, lalu hasil dari uji coba satu di analisis dan di konsultasikan dengan ahli

5. Revisi produk, merevisi produk yang telah dievaluasi dari dosen ahli yang akan diuji cobakan di sekolah

6. Uji coba skala kecil, uji coba skala kecil dilakukan dengan menggunakan 10 orang pemain atau siswa tunagrahita

7. Melakukan revisi produk pertama dari hasil evaluasi oleh para ahli dan uji coba satu atau skla kecil yang dilaksanakan sebelumnya

8. Melakukan ujicoba skala besar dengan menggunakan 20 orang pemain di lapangan dengan skala besar menggunakan model permainan Olahraga Freeball dalam pembelajaran penjas adaptif yang sudah direvisi sebelumnya atas uji coba satu

9. Revisi produk akhir, dilakukan berdasarkan evaluasi dan uji coba dua.

10. Hasil akhir berupa model permainan Olahraga Freeball untuk meningkatkan motorik pada anak Tunagrahita di SLB ABC Swadaya Kendal yang dihasilkan melalui revisi setelah dilakukan uji coba dua dengan skala besar

Uji coba produk dilakukan untuk mendapatkan data yang akan dijadikan dasar untuk menetapkan tingkat tingkat kualitas produk yang akan dihasilkan. Uji coba produk 
pengembangan akan dilaksanakan melalui dua tahapan, yaitu:

1. Tahapan Uji Coba I yakni tahapan uji coba yang melibatkan 10 siswa untuk melakukan percobaan dengan kelompok atau skala kecil, dan selanjutnya hasil dari uji coba satu dilakukan evaluasi dan perbaikan. Pelaksanaan uji coba satu dilakukan di lapangan sekolah SLB ABC Swadaya Kendal.

2. Tahapan Uji Coba II adalah tahapan uji coba yang dilaksanakan di lapangan sekolah SLB ABC Swadaya Kendal dengan melibatkan 20 orang siswa. Pada tahapan ini dilakukan uji coba dua dan selanjutnya hasil dari uji coba dua di evaluasi dan di analiss serta dilakukan penyempurnaan produk akhir.

3. Instrumen Pengumpulan Data pada penelitian ini menggunakan Angket dapat berupa pertanyaa atau pernyataan tertutup atau terbuka. Menurut Edo Dwi Nurcahyo 2018, Sugiyono (2012: 172) jenis-jenis angket menurut bentuknya dibagi tiga, yaitu a. Angket pilihan ganda, b. Check list dan c. Skala bertingkat (rating scale). Oleh Erfiyanto Dwi Nugraha 2017: 27).

Teknik analisis data merupakan cara untuk mengetahui hasil penelitian yang dilakukan. Teknik dalam penelitian ini menggunakan teknik analisa kualitatif yang bersifat penilaian berupa saran dan masukan dan kuantitatif yang bersifat penelitian menggunakan angka. Efriyanto Dwi Nugraha (2017: 28).

Rumus perhitungan kelayakan menurut (Edo Dwi Nucahyo 2018). Dalam Sugiyono (2013: 559) adalah sebagai berikut :

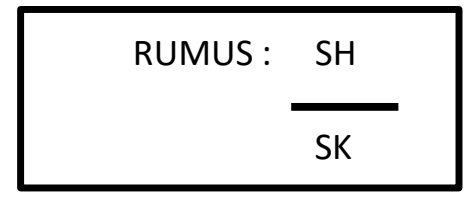

Keterangan :

SH : Skor Akhir

SK : Skor Kriteria/ldeal.

\section{HASIL DAN PEMBAHASAN}

\section{HASIL}

\section{Hasil Uji Coba Skala Kecil}

Hasil analisis uji coba skala kecil yang dilakukan oleh siswa tunagrahita di SLB Abc Swadaya Kendal berjumlah 10 siswa, dari hasil uji coba yang dilakukan oleh 10 responden tersebut mempraktekkan permainan olahraga freeball dapat disimpulkan, bahwa penelitian pada uji coba skala kecil yang dilakukan 10 siswa anak tunagrahita di sekolah pertama yaitu SLB ABC Swadaya mempraktekkan permainan olahraga freeball diperoleh hasil dari 10 responden 90\% (9 siswa) menyatakan layak. Sedangkan $10 \%$ sisanya atau (1 siswa) menyatakan cukup layak. Dari hasil penelitian atau uji coba skala kecil di SLB ABC Swadaya Kendal Pengembangan Model Permainan Olahraga Freeball pada pembelajaran penjas adaptif anak tunagrahita bisa dikatakan layak.

\section{Hasil Uji Coba Skala Besar}

Pada uji coba skala besar yang dilakukan oleh 20 siswa tunagrahita di SLB Negeri Kendal dalam melakukan permainan olahraga freeball diperoleh hasil 18 responden dengan persentase $90 \%$ (18 siswa tunagrahita) menyatakan layak dan 2 responden $10 \%$ (2 siswa tunagrahita) menyatakan cukup layak. Dari hasil uji coba skala besar dapat disimpulkan bahwa $90 \%$ siswa tunagrhita menyatakan layak dan $10 \%$ siswa tunagrahita menyatakan cukup layak yang berarti bahwa permainan olahraga freeball pada pembelajaran penjas adaptif anak tunagrahita dinyatakan layak. uji coba skala besar yang dilakukan oleh 20 siswa tunagrahita di SLB Negeri Kendal dalam melakukan permainan olahraga freeball diperoleh hasil 18 responden dengan persentase $90 \%$ (18 siswa tunagrahita) menyatakan layak dan 2 responden $10 \%$ (2 siswa tunagrahita) menyatakan cukup layak. Dari 
hasil uji coba skala besar dapat disimpulkan bahwa $90 \%$ siswa tunagrhita menyatakan layak dan $10 \%$ siswa tunagrahita menyatakan cukup layak yang berarti bahwa permainan olahraga freeball pada pembelajaran penjas adaptif anak tunagrahita dinyatakan layak.

\section{PEMBAHASAN}

Olahraga Freeball adalah modifikasi dari olahraga futsal dan handball yang telah dirubah peraturan serta cara permainannya lebih sederhana untuk diterapkan pada anak berkebutuhan khusus tunagrahita. Permainan ini dibuat berdasarkan permasalahan yang timbul di sekolah SLB yang berhubungan dengan aktivtas pendidikan jasmani. permasalahan yang ditemukan pada saat observasi disekolah, antara lain kurangnya aktivitas olahraga dan juga kesulitan anak tunagrahita dalam melakukan aktivitas permainan olahraga bola besar. Dikarenakan peraturan serta permainan dalam olahraga bola besar sangat rumit dan sulit dipahami oleh anak tunagrahita, diantaranya cara melakukan passing, dribbling serta pemahaman peraturannya. Kebanyakan mereka hanya melakukan aktivitas olahraga bola besar dengan melempar bola tanpa adanya permainan kompetisi atau kerjasama tim. padahal olahraga yang membutuhkan kerjasama antar tim akan membentuk suatu karakter yang baik dan positif pada anak. Seperti, saling menghargai satu sama lain, kerjasama, kepercayaan diri, kedisiplinan, serta aktivitas gerak aktif dalam permainan yang akan melatih kemampuan motorik pada anak tersebut. Bahkan, dalam kurun waktu satu minggu pernah tidak melakukan aktivitas olahraga sama sekali dikarenakan tidak adanya guru penjas yang khusus mengajar pendidikan jasmani adaptif. Hal ini akan menghambat pertumbuhan serta perkembangan organ yang ada dalam dirinya, mengingat di usia pertumbuhan mereka justru membutuhkan banyak aktivitas gerak agar organ yang ada dalam dirinya dapat tumbuh dan berkembang pada semestinya.

Permainan olahraga freeball juga dapat membentuk suatu karakter yang baik pada anak. Dalam permainan ini dibutuhkan kerjasama antar tim untuk memenangkan pertandingan atau permainannya, hal ini akan memunculkan tindakan saling menghargai satu sama lain, kerjasama, motivasi, kedisiplinan dan kepercayaan diri pada anak tunagrahita yang akan berdampak positif terhadap karakter anak tunagrahita tersebut. Berdasarkan dari hasil penelitian di sekolah SLB diperoleh hasil uji coba skala kecil yang dilakukan oleh 10 responden 9 siswa/responden menyatakan layak dengan persentase $90 \%$ sedangkan ada 1 orang siswa yang menyatakan cukup layak dengan persentase $10 \%$ hasil tersebut dapat disimpulkan bahwa pengembangan model permainan olahraga freeball pada pembelajaran penjas adaptif anak tunagrahita bisa dikatakan layak. Sedangkan dari hasil uji coba skala besar yaitu diperoleh dari 20 responden/siswa, 18 menyatakan layak dengan persentase $90 \%$ dan 2 responden/siswa menyatakan cukup layak dengan persentase 10\%. Yaitu kesimpulan berdasarkan hasil uji coba skala kecil dan uji coba skala besar permainan olahraga freeball dinyatakan berhasil dalam uji coba kelayakan dan dapat digunakan di sekolah SLB.

\section{KESIMPULAN DAN REKOMENDASI}

Berdasarkan hasil penelitian dan pengembangan model permainan olahraga freeball pada pembelajaran penjas adaptif anak tunagrahita di SLB se-kabupaten kendal terdapat beberapa kesimpulan, yaitu siswa anak 
berkebutuhan khusus tunagrahita sangat antusias mengikuti permainan olahraga freeball, mereka juga memberi nilai permainan dalam angket yang disebarkan pada tahap skala kecil dengan kelayakan $90 \%$ dari 10 siswa menjawab layak sedangkan pada skala besar $90 \%$ dari 20 siswa menjawab layak. Oleh karena itu dapat disimpulkan bahwa pengembangan model permainan olahraga freeball pada pembelajaran penjas adaptif anak tunagrahita di SLB sekabupaten kendal yang ternyata layak untuk digunakan setelah dilakukan dua tahap uji coba berupa uji coba skala kecil dan uji coba skala besar. Penelitian pengembangan ini semoga dapat digunakan dan diteruskan oleh para peneliti selanjutnya sehingga dapat menambah wawasan maupun referensi guru dan siswa dalam menerapkan permainan olahraga freeball dalam pembelajaran penjas adaptif di sekolah.

Dari hasil penelitian yang dilakukan di sekolah SLB ABC Swadaya Kendal dan SLB Negeri Kendal masih kurang maksimal, ada beberapa siswa yang masih belum memahami permainan dan juga kesulitan dalam melakukan teknik dasar dalam permainan olahraga freeball terutama dribbling, dikarenakan kebanyakan mereka yang baru pertama kali melakukannya. Ada beberapa saran dan masukan bagi pemain dan pelatih yaitu, sebagai berikut.

(1) Diperlukan melakukan latihan secara rutin, jika perlu dilakukan dirumah terutama teknik dasar seperti dribbling maupun passing sehingga akan terbiasa melakukan gerak dan feeling terhadap bola. Adanya penelitian pengembangan ini juga membantu siswa menambah pengetahuan ilmu baru serta permainan freeball yang telah disederhanakan peraturan permainan di dalam olahraga freeball nya, sehingga siswa dapat melakukan permainan bola besar yang sebelumnya merasa kesulitan karena rumitnya peraturan permainan bola besar yang sulit dipahami siswa tunagrahita pada umumnya.

(2) Diharapkan dapat menyediakan segala sarana dan prasarana di sekolah serta membiasakan siswa untuk aktif bergerak dalam pembelajaran penjas supaya organ yang ada dalam tubuhnya dapat tumbuh dan berkembang pada semestinya mengingat di usia pertumbuhan mereka juga butuh aktivitas olahraga agar tubuh tetap bugar, oleh karena itu pengembangan permainan olahraga freeball sebagai alat untuk mereka melakukan aktivitas gerak dalam pembelajaran penjas adaptif dan permainan bola besar di sekolah SLB

\section{DAFTAR PUSTAKA}

Mahardika. 2008. Pengantar Evaluasi Pengajaran. Surabaya: Unesa.

Subagyo, dkk. 2008. Perencanaan Pembelajaran Penjas. Jakarta: Universitas Terbuka.

Dwi Siswoyo. 2007. Ilmu Pendidikan. Yogyakarta: UNY Pers.

Abdullah, Arma. 1996. Pendidikan Jasmani Adaptif. Jakarta: Departemen Pendidikan Kebudayaan, Diretora Jenderal Pendidikan Tenaga Akademik.

Darmawanti, Ira dan M. Jannah. 2004. Tumbuh Kembang Anak Usia Dini dan Reaksi Dini Pada Anak Berkebutuhan Khusus. Surabaya: Insight Indonesia.

Moh. Amin. 1997. Ortopedagogik Anak Tunagrahita. Bandung: Depdikbud Dirjen Dikti.

Jaya, Asmar. 2008. Futsal Gaya Hidup, Peraturan dan Tips-tips Permainan. Yogyakarta: Pustaka Timur.

Mahendra, Agus. 2000. Bola Tangan. Jakarta: Depdiknas.

Sugiyono. 2012. Metode Penelitian Pendidikan, Pendekatan Kuantitatif, Kualitatif dan R\&D. Bandung: Alfabeta.

Arikunto, Suharsimi. 2006. Prosedur Penelitian Suatu Pendekatan Praktek. Jakarta: PT. Rineka Cipta. 
Apriyanto, Nunung. 2012. Seluk-beluk Tunagrahita \& Strategi Pembelajarannya. Yogyakarta: Javalitera.

Suherman, Adang. 2004. Dasar-dasar Penjas. Jakarta: Depdiknas.

Atmaja, Jati Rinarki. 2018. Pendidikan dan Bimbingan Anak Berkebutuhan Khusus. Bandung: PT Remaja Rosdakarya.

Suharmini, Tin. 2009. Psikologi Anak Berkebutuhan Khusus. Yogyakarta: Kanwa Publisisher.

Effendi, Mohammad. 2006. Psikopedagogik Anak Berkelainan. Jakarta: Bumi Aksara.

Yeni Meimulyani dan Caryoto. 2011. Media Pembelajaran Penjas Adaptif. Jakarta: Luxima 